\title{
Detecting groundwater discharge dynamics from point-to-catchment scale in a lowland stream: combining hydraulic and tracer methods
}

\author{
J. R. Poulsen ${ }^{1}$, E. Sebok ${ }^{2}$, C. Duque ${ }^{3}$, D. Tetzlaff ${ }^{4}$, and P. K. Engesgaard ${ }^{2}$ \\ ${ }^{1}$ Department of Bioscience, Aarhus University, Silkeborg, Denmark \\ ${ }^{2}$ Department of Geosciences and Natural Resource Management, University of Copenhagen, Copenhagen, Denmark \\ ${ }^{3}$ Department of Geosciences, Section of Geology and Geophysics, University of Oslo, Oslo, Norway \\ ${ }^{4}$ Northern Rivers Institute, School of Geosciences, Aberdeen University, Aberdeen, Scotland, UK \\ Correspondence to: J. R. Poulsen (jpo@bios.au.dk)
}

Received: 26 August 2014 - Published in Hydrol. Earth Syst. Sci. Discuss.: 1 December 2014

Revised: 20 March 2015 - Accepted: 22 March 2015 - Published: 21 April 2015

\begin{abstract}
Detecting, quantifying and understanding groundwater discharge to streams are crucial for the assessment of water, nutrient and contaminant exchange at the groundwater-surface water interface. In lowland agricultural catchments with significant groundwater discharge this is of particular importance because of the risk of excess leaching of nutrients to streams. Here we aim to combine hydraulic and tracer methods from point-to-catchment scale to assess the temporal and spatial variability of groundwater discharge in a lowland, groundwater gaining stream in Denmark. At the point-scale, groundwater fluxes to the stream were quantified based on vertical streambed temperature profiles (VTPs). At the reach scale $(0.15-2 \mathrm{~km})$, the spatial distribution of zones of focused groundwater discharge was investigated by the use of distributed temperature sensing (DTS). Groundwater discharge to the stream was quantified using differential gauging with an acoustic Doppler current profiler (ADCP). At the catchment scale $\left(26-114 \mathrm{~km}^{2}\right)$, runoff sources during main rain events were investigated by hydrograph separations based on electrical conductivity (EC) and stable isotopes ${ }^{2} \mathrm{H} /{ }^{1} \mathrm{H}$. Clear differences in runoff sources between catchments were detected, ranging from approximately $65 \%$ event water for the most responsive sub-catchment to less than $10 \%$ event water for the least responsive sub-catchment. This was supported by the groundwater head gradients, where the location of weaker gradients correlated with a stronger response to precipitation events. This shows a large variability in groundwater discharge to the stream, despite the similar lowland characteristics of sub-catchments indicating the usefulness of
\end{abstract}

environmental tracers for obtaining information about integrated catchment functioning during precipitation events. There were also clear spatial patterns of focused groundwater discharge detected by the DTS and ADCP measurements at the reach scale indicating high spatial variability, where a significant part of groundwater discharge was concentrated in few zones indicating the possibility of concentrated nutrient or pollutant transport zones from nearby agricultural fields. VTP measurements confirmed high groundwater fluxes in discharge areas indicated by DTS and ADCP, and this coupling of ADCP, DTS and VTP proposes a novel field methodology to detect areas of concentrated groundwater discharge with higher resolution.

\section{Introduction}

Groundwater and surface-water exchange dynamics are of great importance for a broad range of disciplines within the field of hydrology. For instance, groundwater discharge to streams governs the transfer of solutes and nutrients between sub-surface and surface-water environments (Boulton et al., 2010; Dahl et al., 2007; Gooseff, 2010; Kasahara and Hill, 2008; Krause et al., 2008) and is also a key parameter in controlling stream biodiversity (Malcolm et al., 2003; Hayashi and Rosenberry, 2002). Zones of groundwater recharge and discharge are particularly important in lowland groundwaterdominated streams as many lowland areas are intensively used for agriculture, which significantly increases the risk of transport of nutrients and pollutants to streams with the po- 
tential of severe consequences for stream ecology (Hoffmann and Baattrup-Pedersen, 2007; Kronvang et al., 2005); this is a pressing issue for instance in relation to lowering nutrient loads to rivers, lakes and seas (Danish Ministry of Environment, 2011; Griffith et al., 2006).

Controlled by a range of complex temporal and spatial processes governed by topography, catchment geology, hydrology and hydrometeorology (Brunke and Gonser, 1997; Winter, 1999), the exchange between groundwater and surface water is often spatially and temporally highly variable. Thus, the detection and quantification of groundwatersurface water dynamics present a challenge, particularly in lowland streams. In these streams the diffuse groundwater discharge along the stream channel reduces the sensitivity of thermal methods (Lowry et al., 2007; Krause et al., 2012), as well as tracer methods (Gonzales et al., 2009), and can cause low net increase in stream flow which also limits the available methods for detecting groundwater discharge (Briggs et al., 2011). At the same time due to the presence of focused, significant discharge zones (Lowry et al., 2007; Matheswaran et al., 2012) the spatial variability of groundwater discharge can be large (Krause et al., 2012). Therefore, there is a need to improve our understanding of these processes in lowland catchments across spatial scales in order to develop new approaches and simple tools to map and quantify them.

Different studies applying a range of hydraulic and tracer approaches have been summarised by, for instance, Kalbus et al. (2006). Groundwater fluxes at specific point locations have been measured in rivers by use of seepage metres, revealing large heterogeneity within metres (Landon et al., 2001; Langhoff et al., 2006; Rosenberry, 2008). This spatial heterogeneity has been confirmed by use of temperature as a natural tracer (Conant, 2004), where punctual vertical groundwater fluxes have been estimated from vertical sediment temperature profiles (VTPs) using the steady-state analytical solution to the 1-D conduction-convection equation (Schmidt et al., 2007; Jensen and Engesgaard, 2011) and streambed temperature time series (Hatch et al., 2006; Keery et al., 2007).

At the reach scale more integrated measures, such as differential flow gauging (McCallum et al., 2012; Briggs et al., 2011), have been applied to quantify net differences in stream discharge caused by groundwater recharge and discharge. The use of this method, however, is limited by the measurement uncertainty which prevents it from being applied for detecting small changes in groundwater discharge (Briggs et al., 2011). However, recent advances of acoustic Doppler current profiler (ADCP) instruments for stream discharge measurements open up new possibilities for a more detailed detection of net groundwater discharge with short measurement periods and with a high precision (Mueller and Wagner, 2009). Furthermore, distributed temperature sensing (DTS) has become a widely used method for reach-scale detection of groundwater discharge to streams by monitoring temperatures at the sediment-water interface along a fiber optic cable of several km length (Selker et al., 2006a; Tyler et al., 2009). Thereby, groundwater-surface water interactions can be detected over longer stream sections bridging the monitoring gap between point flux estimates and more integrated measures of net differences in stream discharge at the reach scale (Lowry et al., 2007).

However, most field studies presenting measurements of groundwater-surface water dynamics are carried out in stream sections of a few hundred metres (Conant, 2004; Lowry et al., 2007; Anibas et al., 2011), primarily due to the labour intensive work needed to extend measurements to quantify discharge fluxes beyond the kilometre scale. To obtain information about runoff sources at the catchment scale a common approach is stream hydrograph separations, often conducted by use of stable isotopes and chemical tracers (Sklash and Farvolden, 1979; Uhlenbrook and Hoeg, 2003). However, such hydrograph separations only reveal the integrated catchment response of the point-to-reach-scale groundwater-surface water dynamics, and have rarely been conducted in lowland agricultural catchments. The reason for this is that it can be difficult to clearly identify end members due to the damping of signals by the often constant, strong groundwater influence (Gonzales et al., 2009).

Since the large heterogeneity in groundwater-surface water interactions can be observed across scales, the necessity of combining the different hydraulic and tracer methods is widely recognised (Bencala et al., 2011; Kalbus et al., 2006; Lischeid, 2008; Scanlon et al., 2002) in order to avoid incorrect inferences regarding exchange processes based on observations at one spatial scale only (Schmadel et al., 2014). Hence, more recently point-to-reach-scale groundwater-surface water interactions have been studied by applying multiple methods covering different spatial scales such as groundwater head gradients and DTS (Krause et al., 2012); differential flow gauging, chemical tracers and DTS (Briggs et al., 2011); or chemical tracers and differential flow gauging (McCallum et al., 2012). However, either the studies did not detect small-scale spatial variability in groundwater discharge (Briggs et al., 2011; McCallum et al., 2012) or did not quantify discharge fluxes at the identified discharge zones (Krause et al., 2012). Furthermore, to our knowledge no study has so far combined point-to-reach-scale DTS, VTPs and differential gauging with catchment-scale tracer-based hydrograph separations.

The aim of this study was to combine hydraulic methods (ADCP, groundwater head gradients) and tracer methods (hydrograph separations from electrical conductivity (EC) and ${ }^{2} \mathrm{H} /{ }^{1} \mathrm{H}$, DTS and VTPs) across spatial scales to assess the temporal and spatial variability of groundwater discharge in a lowland, groundwater gaining stream in Denmark. The specific objectives were to (1) assess the spatial variability of groundwater discharge and quantify the fluxes along a $2 \mathrm{~km}$ stretch of the stream by combining high precision ADCP differential flow gauging (intervals of $150-200 \mathrm{~m}$ ) with a novel coupling of DTS (spatial resolution of $1 \mathrm{~m}$ ), and VTPs (point 

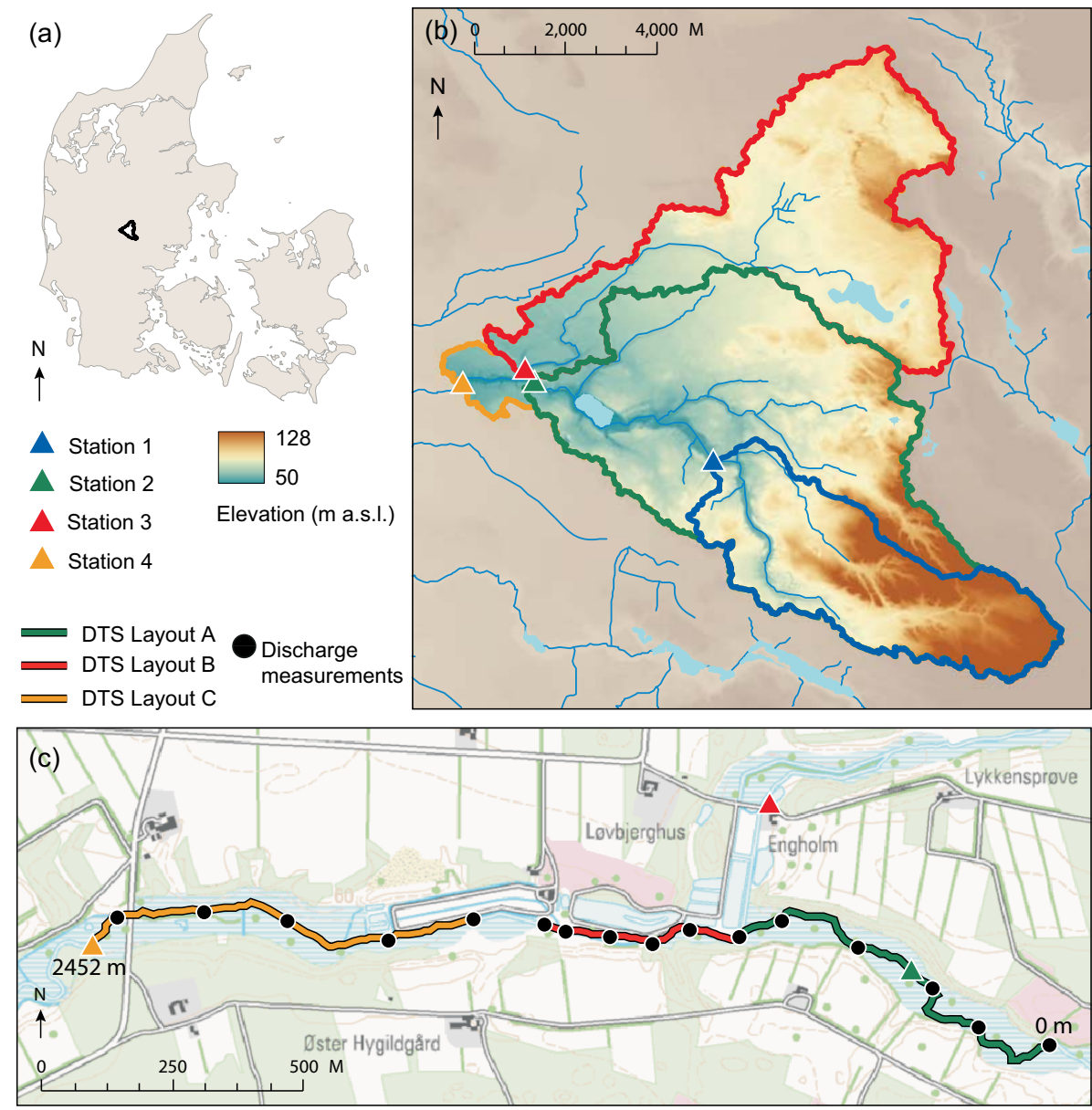

Figure 1. Map of the study area and sampling sites. (a) Map of the study area in Jutland, Denmark, showing the Skjern River catchment and sampling sites. At this site, the stream flows from east to west. (b) Locations of the stations of event samplings and their corresponding catchments. (c) The campaign measurements conducted between station 2 and station 4 .

measurements); (2) investigate variability in runoff sources at the catchment scale $\left(42-114 \mathrm{~km}^{2}\right)$ by stream tracer hydrograph separation and groundwater head gradients; and (3) assess the capability, limitations and synthesis of methods applied across the different scales in terms of water management practices.

\section{Study area}

The study was carried out in the groundwater gaining lowland Holtum stream, located in the Skjern river catchment in Jutland, western Denmark (Fig. 1a). This glacial floodplain valley is characterised by thick sediment deposits of sand and silt deposited during the latest Weichsel glacial period (Houmark-Nielsen, 1989), and with podzols being the dominating soil layers. The mean annual precipitation in the catchment is $950-1000 \mathrm{~mm}$ with an actual evapotranspiration of $460-480 \mathrm{~mm} \mathrm{yr}^{-1}$ (Ringgaard et al., 2011). Average annual air temperature in the catchment was $7.5^{\circ} \mathrm{C}$ in 2012 with stream temperatures between 1 and $16{ }^{\circ} \mathrm{C}$ during the year. The average annual discharge at the catchment outlet was $1.2 \mathrm{~m}^{3} \mathrm{~s}^{-1}$ and the 5 th and 95th percentiles were 0.7 and $2.1 \mathrm{~m}^{3} \mathrm{~s}^{-1}$, respectively, for the period 1994-2012.

The study catchment at Holtum stream was divided into four sub-catchments, and at each sub-catchment outlet a monitoring station was established (Fig. 1b). Three stations were located in the main stream network (stations 1,2 and 4) and one station (station 3) was located in a tributary (Fig. 1b and c) which confluences with the main stream between stations 2 and 4 . The point and reach-scale measurements were conducted between stations 2 and 4 and the catchment-scale investigations were carried out at each of the four stations.

Between stations 1 and 4, the stream flows from east to west with a mean gradient of $1 \%$ receiving four main tributaries (Fig. 1b). Between stations 2 and 4 there is a small inlet from a fishery, constantly carrying a discharge of $0.07 \mathrm{~m}^{3} \mathrm{~s}^{-1}$. Beyond a riparian zone of approximately $5 \mathrm{~m}$, station 1 is surrounded by agricultural fields, whereas the near-stream areas at stations 2,3 and 4 are wetlands. 


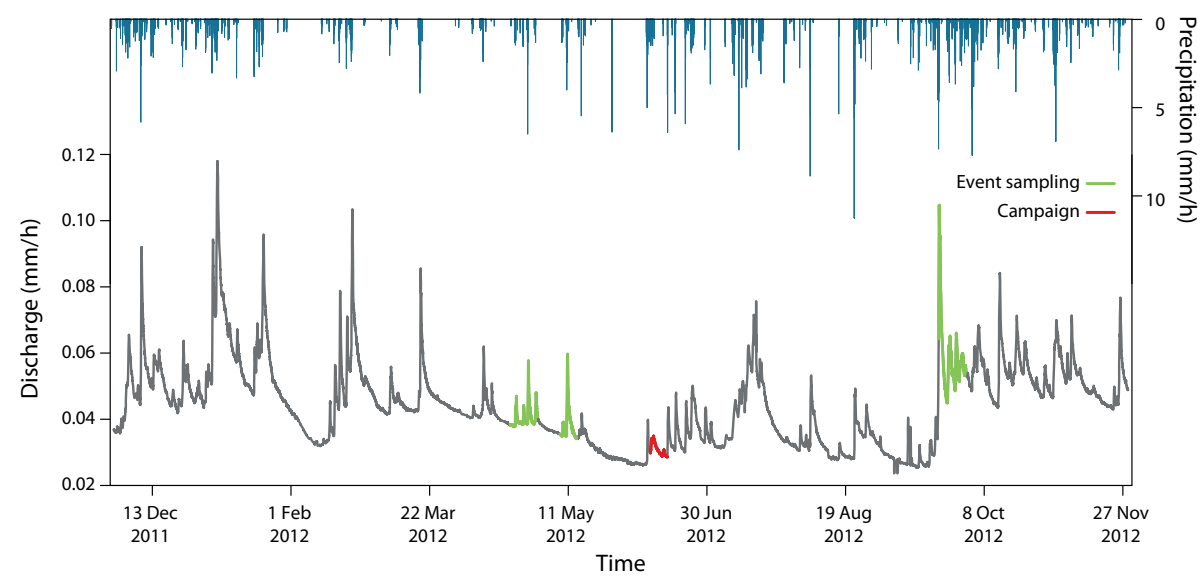

Figure 2. Precipitation and discharge during 2011-2012. Upper part: hourly precipitation measured 6 km northwest of station 4. Lower part: the measured discharge at the catchment outlet (station 4).

Table 1. Catchment characteristics and land use for each sub-catchment, with mean annual discharge, catchment size, specific discharge, distance from the source* and land use.

\begin{tabular}{llrrrrr}
\hline & $\begin{array}{l}\text { Mean } \\
\text { annual } \\
\text { discharge, } \\
\mathrm{m}^{3} \mathrm{~s}^{-1}\end{array}$ & $\begin{array}{r}\text { Catchment } \\
\text { size, } \\
\mathrm{km}^{2}\end{array}$ & $\begin{array}{r}\text { Distance } \\
\text { from the } \\
\text { source, } \\
\mathrm{km}\end{array}$ & $\begin{array}{r}\text { Urban } \\
\%\end{array}$ & $\begin{array}{r}\text { Agriculture } \\
\%\end{array}$ & $\begin{array}{c}\text { Forest } \\
\%\end{array}$ \\
\hline Station 1 & 0.17 & 26 & 6.6 & 27 & 51 & 20 \\
Station 2 & 0.8 & 70 & 12.7 & 21 & 56 & 22 \\
Station 3 & 0.28 & 42 & 11.6 & 16 & 41 & 41 \\
(tributary) & & 114 & 14.7 & 13 & 53 & 34 \\
Station 4 & 1.2 & & & & & \\
\hline
\end{tabular}

* For station 3 it is distance to the source of the tributary.

The mean annual discharge, the topographical catchment and land use of sub-catchments to each station are summarised in Table 1. Hourly precipitation data were available from the Voulund field site, located $6 \mathrm{~km}$ from station 4.

\section{Methods}

For the point-to-reach-scale investigations, a 1 week campaign was carried out between stations 2 and 4 during the low-flow period of 9-15 June 2012 where point-scale VTPs and reach-scale DTS and ADCP measurements were conducted (Fig. 1c). The low-flow period was chosen to minimise the risk of surface discharge to the stream. The catchment-scale studies were conducted during three different rain events in 2012, one in spring, one in summer and one in autumn (Fig. 2). The decision of monitoring the three selected rain events were based on weather forecasts of upcoming large rain events, combined with antecedent medium to low stream-flow conditions. During the rain events, samples of stream water were collected at stations 1-4. Stream discharge at the catchment outlet and precipitation values during the investigation period are shown in Fig. 2. In addition, hydraulic heads were measured several times in piezometers installed in riparian zones/wetlands at stations 1, 2 and 4 (relative position of the screens shown on Fig. 3) to define hydraulic conditions at the stations. The different types of measurements are summarised in Table 2.

\subsection{Point-scale measurements}

\subsection{Vertical streambed temperature profiles}

Deeper groundwater temperature in Denmark equals the annual average air temperature of $\sim 8^{\circ} \mathrm{C}$ while the average stream temperature was $13^{\circ} \mathrm{C}$ during the campaign. Therefore, potential groundwater discharge sites were expected to show relatively low streambed temperatures during the field campaign. Point-scale vertical groundwater fluxes were estimated based on VTPs in low streambed temperature zones, as indicated by the DTS surveys. At these locations, streambed temperatures were collected after a $10 \mathrm{~min}$ equilibration time at $0,0.025,0.05,0.075,0.1,0.15,0.2,0.3$, 0.4 and $0.5 \mathrm{~m}$ below the streambed by thermocouples with an accuracy of $0.2^{\circ} \mathrm{C}$. Due to the long equilibration time needed, VTP measurements were only collected at locations 

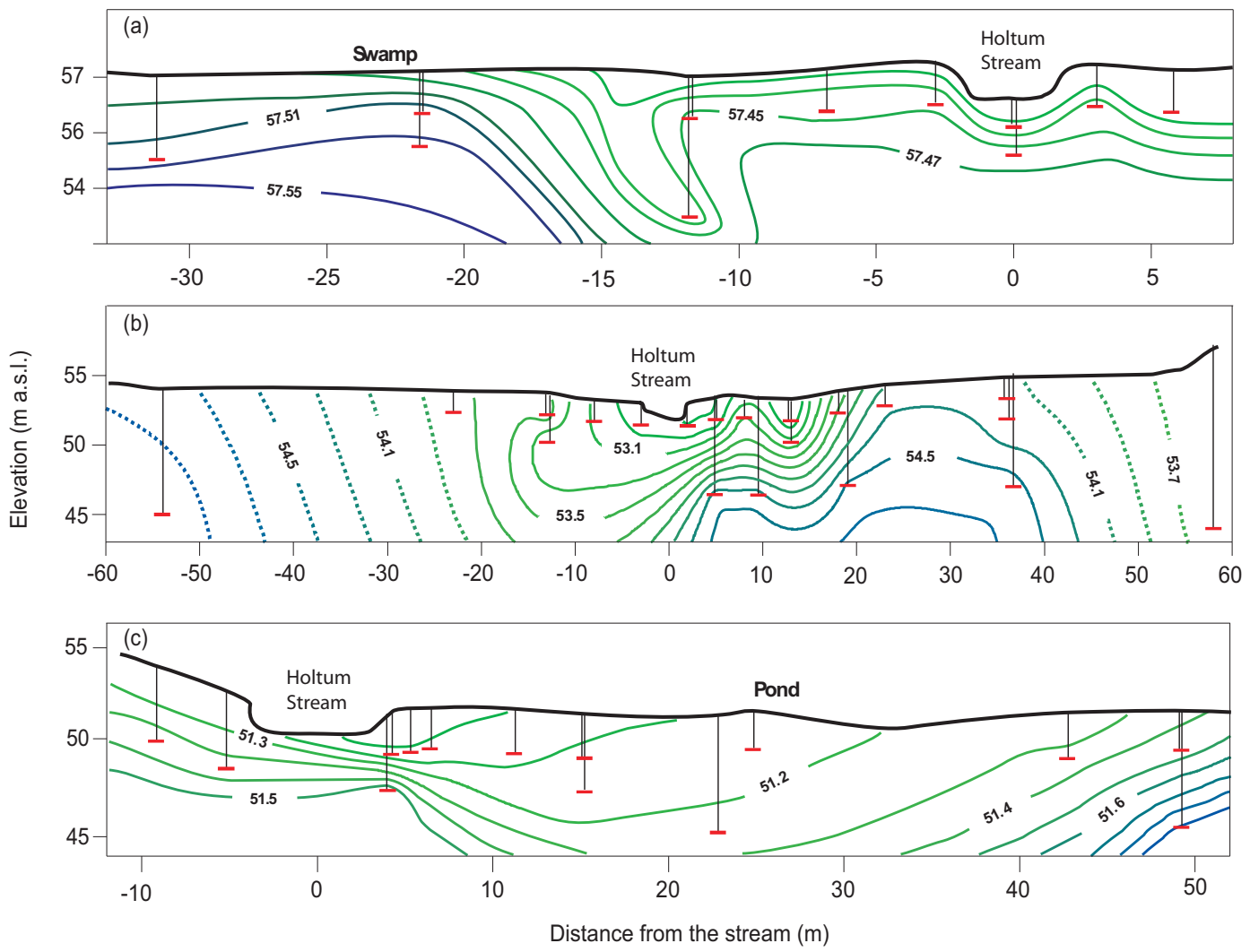

Figure 3. Manually interpolated cross-sectional contour maps of hydraulic heads. (a) Cross section at station 1 based on data from February 2013. (b) Cross section at station 2 based on data from June 2013. (c) Cross section at station 4 based on data from March 2012. The horizontal red lines represent the screen depth of the piezometers where hydraulic heads were measured. Dashed isopotential lines indicate areas with sparse data coverage.

where DTS indicated the most pronounced potential discharge locations.

Based on the VTP measurements, vertical groundwater fluxes were estimated by fitting the steady-state analytical solution of the one-dimensional conduction-convection equation (Bredehoeft and Papadopulos, 1965) to the measured temperature data as described by Schmidt et al. (2007) and Jensen and Engesgaard (2011):

$T(z)=T_{\mathrm{S}}+\left(T_{\mathrm{g}}-T_{\mathrm{S}}\right) \frac{\exp \left(\frac{N_{\mathrm{pe}} z}{L}-1\right)}{\exp \left(N_{\mathrm{pe}}-1\right)}$,

where $T(z)$ is the streambed temperature $\left({ }^{\circ} \mathrm{C}\right)$ measured at depth $z(\mathrm{~m}), T_{\mathrm{s}}$ is the stream water temperature $\left({ }^{\circ} \mathrm{C}\right), T_{\mathrm{g}}$ is the groundwater temperature $\left({ }^{\circ} \mathrm{C}\right)$ at a given depth $L(\mathrm{~m})$, and $N_{\text {pe }}$ is the Peclet number giving the ratio of convection to conduction:

$N_{\mathrm{pe}}=\frac{q_{z} \rho_{\mathrm{f}} c_{\mathrm{f}} L}{\kappa_{\mathrm{e}}}$,

where $q_{z}\left(\mathrm{~m} \mathrm{~s}^{-1}\right)$ is the vertical fluid flux, $\rho_{\mathrm{f}} c_{\mathrm{f}}$ is the volumetric heat capacity of the fluid $\left(\mathrm{J} \mathrm{m}^{-3}{ }^{\circ} \mathrm{C}^{-1}\right)$, and $\kappa_{\mathrm{e}}$ is the effective thermal conductivity $\left(\mathrm{J} \mathrm{m}^{-1} \mathrm{~s}^{-1}{ }^{\circ} \mathrm{C}^{-1}\right)$.
As previous studies (Jensen and Engesgaard, 2011; Karan et al., 2013) in the same area only detected moderate seasonal changes in streambed temperatures, the steady-state conditions were assumed to be valid for the study period in June. For each VTP, $T_{\mathrm{S}}$ was given as the temperature measured by the uppermost sensor, and the constant groundwater temperature of $8^{\circ} \mathrm{C}\left(T_{\mathrm{g}}\right)$ was assumed at a depth of $5 \mathrm{~m}(L)$. A volumetric heat capacity of $4.19 \times 10^{-6} \mathrm{~J} \mathrm{~m}^{-3}{ }^{\circ} \mathrm{C}^{-1}$ was used for the water, and effective thermal conductivity of $1.8 \mathrm{~W} \mathrm{~m}^{-1}{ }^{\circ} \mathrm{C}^{-1}$ was assumed for the sandy streambed.

\subsection{Reach-scale measurements}

\subsubsection{Distributed temperature sensing}

During the June 2012 campaign DTS was used for reachscale investigations of the groundwater discharge dynamics. A BruSteel fiber optic cable connected to a Sensornet OryxSR system was deployed along the middle of the stream on the sediment-water interface in three layouts (A, B and C) to cover the whole length of the stream section (Fig. 1c). To avoid damage of the fiber optic cable, no measurements were 
Table 2. Summary of sampling periods and data collection methods, with the scale covered by the method, the method/instrument and time of measurement.

\begin{tabular}{lll}
\hline Scale & Measurement & Time of measurement \\
\hline Point & VTPs & 9-13 Jun 2012 \\
& Piezometer water sampling & Mar 2012 and Feb 2013 \\
& Piezometer hydraulic heads & Aug 2012, Feb 2013, May 2013 (station 1) \\
& & Dec 2011, Mar 2012, Feb 2013, Jun 2013 (station 2) \\
& & Mar 2012 (station 4) \\
\hline Reach/campaign & ADCP & 9-13 Jun 2012 \\
& DTS & 9-13 Jun 2012 \\
\hline Catchment & EC and $\delta^{2} \mathrm{H}$ & 20-30 Apr 2012, 8-14 May 2012, 21-30 Sep 2012 \\
\hline
\end{tabular}

made between 1366 and $1530 \mathrm{~m}$ in the downstream direction from station 2 (Fig. 1c) due to remnants of a weir.

For each layout streambed temperature data were collected with double-ended measurements of 10 min integration times and a $1.01 \mathrm{~m}$ spatial averaging interval. Each installation was calibrated by running approximately $30 \mathrm{~m}$ fiber optic cable through a calibration bath. The precision of the installations is shown in Table 3. In each layout streambed temperature time series of $22-23 \mathrm{~h}$ were collected with different starting times (Table 3 ), but results are presented by aligning the measurements relative to the time of day. Under the temperature conditions of the June campaign, low streambed temperatures could indicate concentrated discharge zones. However, due to different daily air temperatures, the decrease in streambed temperatures at the potential concentrated discharge sites was not directly comparable between the layouts. Hence, in order to compare streambed temperatures measured at different days at different locations, the strength of the groundwater temperature signal for each measurement location was calculated as

$S_{i}=\frac{\overline{T_{1}}}{\overline{T_{i}}}$,

where $S_{i}$ is the strength of the groundwater temperature signal at location $i, T_{1}$ is the mean temperature measured at the corresponding layout "l" during the measurement period, and $T_{i}$ is the mean temperature at location $i$ during the measurement period. Thus, $S_{i}$ values above one represent colder streambed temperatures than the mean of the layout.

\subsubsection{Differential gauging}

In the $2450 \mathrm{~m}$ long stream section between stations 2 and 4 (Fig. 1c), differential gauging of stream discharge was carried out during the June 2012 campaign for detection of the reach-scale variability of groundwater discharge. Stream discharge was measured with an ADCP StreamPro manufactured by Teledyne RD Instruments. The ADCP StreamPro has a four-beam $2 \mathrm{MHz}$ transducer, a sampling frequency of $1 \mathrm{~Hz}$ and estimates discharge based on measured water ve-
Table 3. Time of DTS stream bed temperature measurements with the length and precision of each layout.

\begin{tabular}{lllc}
\hline & Time of measurement & Length, $\mathrm{m}$ & Precision, ${ }^{\circ} \mathrm{C}$ \\
\hline Layout A & 11 June 13:20-12 June 11:50 & $0-905$ & 0.05 \\
Layout B & 12 June 17:20-13 June 16:00 & $906-1366$ & 0.21 \\
Layout C & 9 June 18:00-10 June 17:20 & 1530-2452 & 0.04 \\
\hline
\end{tabular}

locities and a cross-sectional area. The ADCP is mounted on a platform and tethered across the stream, perpendicular to the main flow direction.

Discharge measurements were conducted for each $200 \mathrm{~m}$ in layout $\mathrm{A}$ and $\mathrm{C}$ and for each $150 \mathrm{~m}$ in layout B (Fig. 1c). The distances of 150 and $200 \mathrm{~m}$ between ADCP discharge measurements were chosen, based on a pilot study conducted in early spring 2012. This pilot study showed that at least $150 \mathrm{~m}$ between measurements were needed to obtain discharge increases larger than $5 \%$. The ADCP measurement procedure was optimised according to recent recommendations (Mueller and Wagner, 2009; Muste et al., 2004a, b) and a minimum of 10 discharge measurements with an average deviation less than or equal to $5 \%$ were made at each location in order to minimise the uncertainty of the discharge estimates. A permanent gauging station was installed at the catchment outlet (station 4) for continuous discharge estimation based on the stage-discharge relation, continuous water stage measurements (OTT Thalimedes pressure transducer) and monthly current metre control measurements of discharge (Rantz, 1982; Herschy, 1999).

\subsection{Catchment-scale measurements}

\subsubsection{Sampling of stream water and precipitation}

Different sources of runoff in the sub-catchments were studied based on the analysis of the stream water EC and stable isotope fractions ${ }^{2} \mathrm{H} /{ }^{1} \mathrm{H}$ during three monitored rain events. Stream water samples were collected with two Teledyne ISCO 6712 and two Teledyne ISCO 3700 portable samplers, with intervals of $3-5 \mathrm{~h}$. Precipitation was collected in a clas- 
sical Hellmann Rain Gauge and bulk water samples for isotope analysis were collected manually. The inner cup of the rain gauge was sealed with a thin plastic cover to protect against evapotranspiration.

The Teledyne samplers were programmed to collect $700 \mathrm{~mL}$ for every sampling, and immediately after each sampling round of 24 samples, subsamples of $20 \mathrm{~mL}$ were taken and sealed in plastic bottles and stored at a temperature of $4^{\circ} \mathrm{C}$. The precipitation samples were sealed and stored in the same manner. The stream water and precipitation samples were analysed for $\delta^{2} \mathrm{H}$ on a PICARRO L2120-i isotopic water spectrometer with isotope fractions given in per mille relative to Vienna Standard Mean Ocean Water (VSMOW). The precision of the measurements was $0.3 \%$ for $\delta^{2} \mathrm{H}$. EC in the precipitation and stream water samples were measured on site with a portable Cond 3310 (WTW, Weilheim) conductivity metre with an accuracy of $\pm 0.5 \%$.

\subsubsection{Hydrograph separation}

To estimate the sources of runoff in the four different sub-catchments during different events, a one-tracer, twocomponent hydrograph separation was conducted (Sklash and Farvolden, 1979). The stream water was separated into pre-event and event water fractions on the basis of the measured $\delta^{2} \mathrm{H}$ signatures. Pre-event water refers to water present in the catchment before the event and event water refers to the water that enters the catchment during the event (Genereux and Hooper, 1998). The mixing equation used to estimate the pre-event fractions is given by

$f_{\mathrm{pe}}=\frac{C_{T}-C_{\mathrm{e}}}{C_{\mathrm{pe}}-C_{\mathrm{e}}}$,

where $C_{T}$ represents the isotopic signature in the stream water, $C_{\mathrm{e}}$ represents the isotopic signature of the event water (rainfall during the events) and $C_{\mathrm{pe}}$ represents the isotopic signature in the pre-event water. The signature in the stream water immediately prior to the events was used as $C_{\text {pe }}$, based on the assumption that the influence from event water at that time is negligible (Pinder and Jones, 1969; Sklash and Farvolden, 1979). For the April and May events sparse precipitation samples were available and $C_{\mathrm{e}}$ was calculated as a weighted mean and a bulk value, respectively. For the September event $C_{\mathrm{e}}$ was calculated as an incremental weighted mean value of the precipitation samples (McDonnell et al., 1990).

An additional chemical one-tracer, two-component hydrograph separation was conducted based on stream water EC. Thereby the fractions of sub-surface and surface water can be estimated, where sub-surface water refers to the water which has passed through the mineral soil, and surface water refers to water which has not infiltrated the mineral soil (Genereux and Hooper, 1998). In the case of an entirely groundwaterdominated stream network, the sub-surface component will be equal to the groundwater component and surface frac- tions will correspond to the rain component (Rodhe, 1998). Hence, any discrepancies between the pre-event and subsurface fractions can indicate the likely presence of additional components (Wels et al., 1991). The same mixing equation (Eq. 4) as used for the $\delta^{2} \mathrm{H}$ signatures was applied, but instead of $C_{\mathrm{e}}$ and $C_{\mathrm{pe}}$ the EC values of the surface component $C_{\mathrm{S}}$ (rainfall) and the subsurface component $C_{G}$ (stream water prior to event), respectively, were used. $C_{T}$ represents the $\mathrm{EC}$ value in the stream water during the event. EC values of the precipitation were calculated as described for the $\delta^{2} \mathrm{H}$ values.

Uncertainties in the pre-event water fractions inherent from uncertainties in determination of the signatures used in Eq. (4) were calculated based on the procedure by Genereux (1998). This method is based on an uncertainty propagation technique using Gaussian error estimators, and was calculated at the 0.05 confidence level. Uncertainties in $\mathrm{EC}$ and $\delta^{2} \mathrm{H}$ values in stream water prior to events were used to determine the uncertainty in $C_{\mathrm{pe}}$ and $C_{G}$. Uncertainties in rainfall and stream water during events were calculated based on the measurement's precision $\left( \pm 0.3 \%\right.$ o for $\delta^{2} \mathrm{H}$ and $0.5 \%$ of measured $\mathrm{EC}$ value) since only one sample per time interval was available.

\section{Results}

\subsection{Spatial variability in groundwater head gradients}

In the majority of the piezometers installed at stations 1,2 and 4 , the groundwater table was less than $2 \mathrm{~m}$ below ground during all measurements conducted in the period December 2011 to June 2013. Due to the limited fluctuations observed in groundwater levels at stations 1,2 and $4(<15 \mathrm{~cm})$, it is assumed that the head gradients depicted in Fig. 3 are representative of the general pattern for the whole study period. The hydraulic heads suggested groundwater upwelling to the stream at all stations, as illustrated by manually interpolated isopotential lines (Fig. 3). However, at station 1, head gradients in the close proximity of the stream were significantly smaller than at station 2 and 4 (Fig. 3a), indicating a less strong upwelling. At station 2, hydraulic heads indicated an upward flow to the right of the stream with very high gradients (Fig. 3b) while rather lateral flow towards the stream seems to dominate the left side of the stream channel. At station 4 to the right of the stream, hydraulic heads indicated an upward flow towards the wetland (Fig. 3c).

\subsection{Detection of point-to-reach-scale spatial variability of focused groundwater discharge}

The results from the point-to-reach-scale investigations conducted during the June 2012 campaign are summarised in Fig. 4. DTS measurements revealed a number of focused groundwater discharge sites with their location generally confirmed by the ADCP differential flow gauging. In layout 


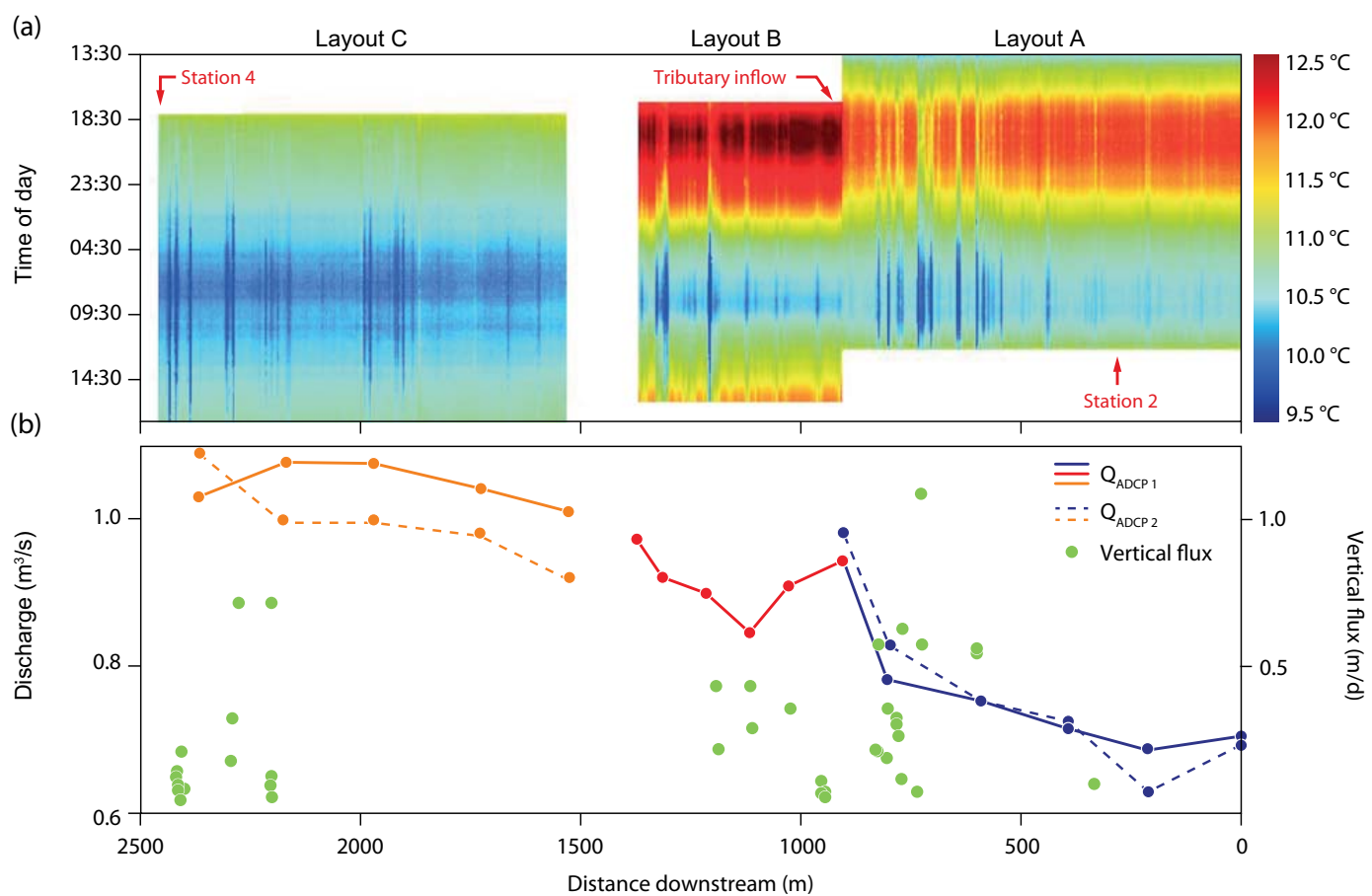

Figure 4. DTS, VTP and ADCP measurements from the campaign sampling in June 2012. (a) DTS temperatures measured in three layouts A, $\mathrm{B}$ and $\mathrm{C}$ between stations 2 and 4. (b) ADCP discharge measurements combined by trend lines. Dashed and solid trend lines represent separate measurement rounds. Uncertainties of the ADCP stream discharge measurements were all below $5 \%$ (not shown). Vertical flux points are estimated based on VTP measurements.

A the ADCP measurements showed only a slight net increase in stream discharge along the first $400 \mathrm{~m}$ coinciding with no distinct temperature anomalies detected by the DTS. However, at $600,640,705,735,800$ and $825 \mathrm{~m}$ in the downstream direction, colder streambed temperatures were detected by the DTS (Fig. 4a) potentially indicating high groundwater discharge supported by an increase in stream discharge of approximately $14 \%$ along the layout (Fig. 4). In the last $200 \mathrm{~m}$ of layout A the inflow of the tributary, which had an average discharge of $0.23 \mathrm{~m}^{3} \mathrm{~s}^{-1}$ during the measurement period, caused the significant increase in stream discharge observed.

Layout B revealed the largest spatial variability in groundwater discharge of the three layouts, with both losing and gaining sections (Fig. 4). The losing section was detected by the ADCP at the beginning of layout B causing the stream discharge to decrease with approximately $13 \%$ (Fig. 4). However, ADCP measurements in the main stream suggested that stream water is already recharging at the very last section of layout $\mathrm{A}$, since only an increase of $0.15 \mathrm{~m}^{3} \mathrm{~s}^{-1}$ is observed despite the inflow of $0.23 \mathrm{~m}^{3} \mathrm{~s}^{-1}$ from the tributary. At the same time, DTS measurements suggested that there were as well some groundwater discharge sites along the losing reach in layout $\mathrm{B}$, reflecting a high spatial variability in groundwater-surface water interactions. No visible outflows such as ditches or ponds at the stream banks were present, and no unusual streambed or bank sediments were detected to explain this loss of stream water. Thus, it is found likely that part of this water loss can be attributed to the fishing lakes bordering the stream where artificial precautions might locally disturb the groundwater head gradients. At 1205 and $1400 \mathrm{~m}$ two potential high discharge sites were identified with DTS which was supported by a concurrent increase in stream discharge of about $7 \%$.

The most gradual net increase in discharge was observed along layout $\mathrm{C}$ by ADCP measurements and confirmed by several cold streambed temperature zones indicated by the DTS, suggesting more diffuse groundwater inflow compared to layout $\mathrm{A}$ and $\mathrm{B}$. In layout $\mathrm{C}$ the most pronounced cold temperature anomalies were detected at the downstream end at 1900, 1980, 2285, 2380 and $2415 \mathrm{~m}$ (Fig. 4a). Due to a rain event on 9 June, the air temperature decreased and therefore the lowest streambed temperatures of all layouts were measured in layout $\mathrm{C}$. The rain event also caused the stream discharge to be slightly higher on average during the first round of measurement compared to the second round (Fig. 4b). However, the event mainly occurred during the evening and night, and only the stream discharge pattern observed between the two most downstream ADCP measurements in layout $\mathrm{C}$ are suspected to be directly influenced by the rain event.

To couple reach-scale groundwater discharge indications and point-scale flux estimates VTP measurements were carried out at 18, 9, and 15 locations in layout A, B and C, respectively, at the locations with the cold temperature anoma- 
Table 4. Summary of rainfall and runoff characteristics with rainfall intensity and duration, peak discharge, maximum discharge increase and number of rain samples for each precipitation event. September is divided into three sub-events.

\begin{tabular}{|c|c|c|c|c|c|}
\hline Event & April & May & September 1 & September 2 & September 3 \\
\hline Precipitation intensity ${ }^{\mathrm{a}}, \mathrm{mm} \mathrm{h}^{-1}$ & 1 & 1.4 & 2.4 & 1.1 & 2.3 \\
\hline Precipitation event duration, $\mathrm{h}$ & 15 & 11 & 15 & 16 & 7 \\
\hline Total rainfall, mm & 15 & 15 & 36 & 18 & 16 \\
\hline Peak discharge ${ }^{\mathrm{b}}, \mathrm{mm} \mathrm{h}^{-1}$ & 0.06 & 0.06 & 0.1 & 0.07 & 0.07 \\
\hline Discharge increase ${ }^{\mathrm{c}}, \%$ & 49 & 70 & 207 & 44 & 35 \\
\hline Number of rainfall samples & 1 & 2 & 4 & 2 & 2 \\
\hline Frequency of stream water samples, $\mathrm{h}$ & 5 & $4.3^{\mathrm{d}}$ & 3 & 3 & 3 \\
\hline
\end{tabular}

${ }^{a}$ Calculated as average precipitation intensity; ${ }^{\mathrm{b}}$ Discharge at station $4 ;{ }^{\mathrm{c}}$ The increase in discharge from immediately before the event to the peak; ${ }^{\mathrm{d}} 4 \mathrm{~h}$ during the first half of the event, $3 \mathrm{~h}$ during the second half of the event.

Table 5. Mean \pm standard deviation of stream water and rainfall EC and $\delta^{2} \mathrm{H}$ signatures used as pre-event $-\left(C_{\mathrm{pe}}\right)$, subsurface $-\left(C_{G}\right)^{\mathrm{a}}$, event $-\left(C_{\mathrm{e}}\right)$ and surface $-\left(C_{\mathrm{S}}\right)^{\mathrm{b}}$ components for the hydrograph separations.

\begin{tabular}{|c|c|c|c|c|c|c|c|c|c|c|}
\hline & \multicolumn{2}{|c|}{ April } & \multicolumn{2}{|c|}{ May } & \multicolumn{2}{|c|}{ September 1} & \multicolumn{2}{|c|}{ September 2} & \multicolumn{2}{|c|}{ September 3} \\
\hline & \multicolumn{10}{|c|}{$C_{\mathrm{pe}}\left(\delta^{2} \mathrm{H}, \% o\right)$ and $C_{G}\left(\mathrm{EC}, \mu \mathrm{S} \mathrm{cm}{ }^{-1}\right)$, mean $\pm \mathrm{SD}$} \\
\hline & $\delta^{2}$ & H EC & $\delta^{2}$ & H EC & $\delta^{2}$ & H EC & $\delta^{2}$ & HEC & $\delta^{2}$ & H EC \\
\hline Station 2 & - & & $-51.2 \pm 0.4$ & $284 \pm 2$ & May eve & & & & & \\
\hline Station 3 & $-52.2 \pm 0.21$ & $286 \pm 4$ & $-51.2 \pm 0.4$ & $283 \pm 3$ & & & & & & \\
\hline Station 4 & $-52.8 \pm 0.42$ & $278 \pm 2$ & $-52.37 \pm 0.2$ & $204 \pm 2$ & & & & & & \\
\hline Rainfall $^{b}$ & -38.4 & 42 & $-44.7 \pm 30.0$ & $81 \pm 41$ & $-71.0 \pm 24.1$ & $84 \pm 76$ & $-55.5 \pm 3$ & $45 \pm 4$ & $-71.6 \pm 9.1$ & $38 \pm 16$ \\
\hline
\end{tabular}

lies as shown by the DTS. The average root mean square error (RMSE) for the fitted temperature profiles was $0.126^{\circ} \mathrm{C}$ between the measured and the modelled temperatures (minimum RMSE: $0.016^{\circ} \mathrm{C}$, maximum RMSE: $0.304^{\circ} \mathrm{C}$ ). Generally, there was an agreement between significant groundwater discharge sections indicated by DTS, ADCP and the estimated vertical fluxes (Fig. 4b). However, a significant spatial variability in the measured fluxes was found. In layout A estimated vertical groundwater fluxes ranged from 0.09 to $1.3 \mathrm{~m} \mathrm{day}^{-1}$ with a mean of $0.44 \mathrm{~m} \mathrm{day}^{-1}$ (Fig. 4b), within short distances. In layout $\mathrm{B}$ a minimum and maximum flux of 0.07 and $0.52 \mathrm{~m} \mathrm{day}^{-1}$ were estimated, the lowest flux occurring along the losing reach. The VTP measurements were carried out at potential discharge sites, correspondingly even in the losing reach the streambed temperature profiles visually indicate upward fluxes by streambed temperatures quickly decreasing below the streambed. Due to firm streambed sediments VTP measurements were only possible at the most downstream end of layout $\mathrm{C}$ there showing vertical flux estimates from 0.06 to $0.86 \mathrm{~m} \mathrm{day}^{-1}$ with a mean of $0.29 \mathrm{~m} \mathrm{day}^{-1}$.

For layout A and B the comparison between estimated upward groundwater fluxes and the strength of the groundwater signal (Eq. 3) at the corresponding DTS locations

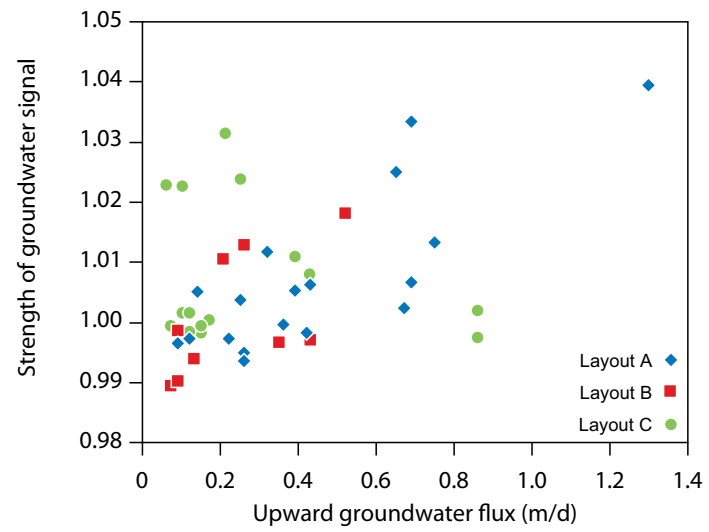

Figure 5. Correlation of the strength of the groundwater signal as recorded by DTS with upward groundwater fluxes estimated from VTPs. Measurements from each layout are separated by colour.

showed a moderate correlation (significant on the $p<0.01$ and $p<0.05$ level, respectively) (Fig. 5). This indicated that higher upward fluxes usually coincided with a stronger groundwater signal. In layout $\mathrm{C}$, however, there was no correlation, potentially due to the smaller temperature difference 
between air and stream water during measurement of that layout.

\subsection{Variability in catchment runoff sources}

The rainfall-runoff conditions during the three monitored events are summarised in Table 4, and the signatures used for calculating the hydrograph separations are shown in Table 5. No stream water samples were collected prior to the September event. However, the May and September events had similar antecedent conditions, and therefore the May pre-event signatures were used as September pre-event and subsurface signatures of EC and $\delta^{2} \mathrm{H}$, respectively.

The variability in stream water $\delta^{2} \mathrm{H}$ and EC during all three events showed a tendency of being more damped in the downstream direction with decreasing standard deviations (Fig. 6) likely reflecting an increased groundwater influence. The smallest variability was observed at station 3 and the largest variability at station 1 , reflecting most of the variability in precipitation input. The events also resulted in three different temporal patterns in tracer values where the largest variability in $\delta^{2} \mathrm{H}$ and EC stream values occurred during the September event (Fig. 6a) and the smallest variability occurred during the April event (Fig. 6b).

The most significant event responses from all four subcatchments were detected during the first part of the September event (Fig. 7). Station 1 showed the quickest and most pronounced response with the pre-event fraction reaching a minimum of $35 \%$ (Fig. 7c) and a recovery time of approximately $9 \mathrm{~h}$ (recovery time is defined as the time it takes to reach pre-event concentrations). Stations 2 and 4 showed delayed and less pronounced event responses compared to station 1 with a minimum of 40 and $55 \%$ pre-event water, respectively (Fig. 7d and f). Station 3 only showed a clear event response on 21 September, with the pre-event fraction being $70 \%$ at the peak of the response (Fig. 7e). This response at station 3 was significantly delayed, approximately $15 \mathrm{~h}$, compared to station 1 , and showed a more gradually increasing response curve. Stations 2, 3 and 4 exhibited similar recovery times, approximately $24 \mathrm{~h}$ (Fig. 7c-f).

Generally, pre-event fractions were similar at all stations during peaks of the different events (Fig. 8a). Station 1 consistently showed the largest event responses and stations 2 and 4 reacted similarly but less pronounced than station 1 . There was a tendency for station 4 to be damped in the preevent responses as compared to station 2 (Fig. 8a). This is expected to be partly due to the inflow from the groundwaterdominated tributary between stations 2 and 4 . Station 3 only showed modest peak response with $\min 70 \%$ pre-event fractions during all events (Fig. 8a). The subsurface fractions showed similar responses at all stations as the pre-event fractions (Fig. 8b). However, with the exception of the September 1 event, the sub-surface fractions for stations 1, 2 and 4 varied significantly less than the pre-event fractions between events (Fig. 8). For instance, at station 4 the sub-surface frac- tions varied only between 80 and $90 \%$, whereas the pre-event fractions varied between 65 and $95 \%$. Calculated uncertainties at the peaks of the event and subsurface fractions depicted in Fig. 8 were all below $10 \%$ (not shown).

\section{Discussion}

\subsection{Spatial variability and magnitude of groundwater discharge from point-to-reach scale}

The point-to-reach-scale investigation confirmed that the studied part of the stream is groundwater dominated. On the reach scale, between station 2 and station 4 , groundwater discharge to the stream resulted in approximately $30 \%$ increase in total stream discharge. However, DTS and VTP measurements showed that the spatial distribution of groundwater discharge in this section is not homogeneous (Fig. 4), similarly to the DTS observations of Lowry et al. (2007), Briggs et al. (2011) and the VTP-based flux estimations of Schmidt et al. (2007) and Anibas et al. (2011). The large spatial variability in groundwater discharge is most likely due to heterogeneity in streambed hydraulic conductivity (Kalbus et al., 2006; Sebok et al., 2014), which was also suggested by the streambed composition with interchanging sand, gravel and clusters of macrophyte growth. The spatial heterogeneity was also reflected at the point scale. Especially in layout $\mathrm{C}$ data showed that even if the DTS streambed temperatures were higher than the mean, that is no high discharge was expected, upward fluxes up to $0.15 \mathrm{~m} \mathrm{day}^{-1}$ could still be measured at the point scale. This suggests that more diffuse groundwater inflow is also significant along the streambed.

DTS measurements have previously been used to locate and calculate groundwater discharge to streams (Selker et al., 2006b; Briggs et al., 2011) based on a temperature mixing approach combined with differential gauging upstream and downstream of discharge sites. The DTS results from June 2012 also showed drops in streambed temperatures of $0.5-1{ }^{\circ} \mathrm{C}$ possibly due to groundwater discharge (Fig. 4). However, instead of large step changes in streambed temperatures (Selker et al., 2006b, Briggs et al., 2011), groundwater discharge did not alter the downstream temperatures as also observed in a wetland stream (Lowry et al., 2007) and in a Danish stream with a significantly lower mean discharge of $0.25 \mathrm{~m}^{3} \mathrm{~s}^{-1}$ (Matheswaran et al., 2012). Thus, quantification of discharge using the traditional mixing analysis based on DTS measured temperatures was not possible due to the small temperature contrast.

Consequently, our results suggest that a significant part of the groundwater discharge along the studied $2.5 \mathrm{~km}$ long reach is concentrated in relatively few focused zones. Hence, most likely the groundwater reaches the stream via preferential flow paths governed by differences in streambed hydraulic conductivity and hydraulic head conditions (Kalbus et al., 2006). Since these focused high discharge zones will 


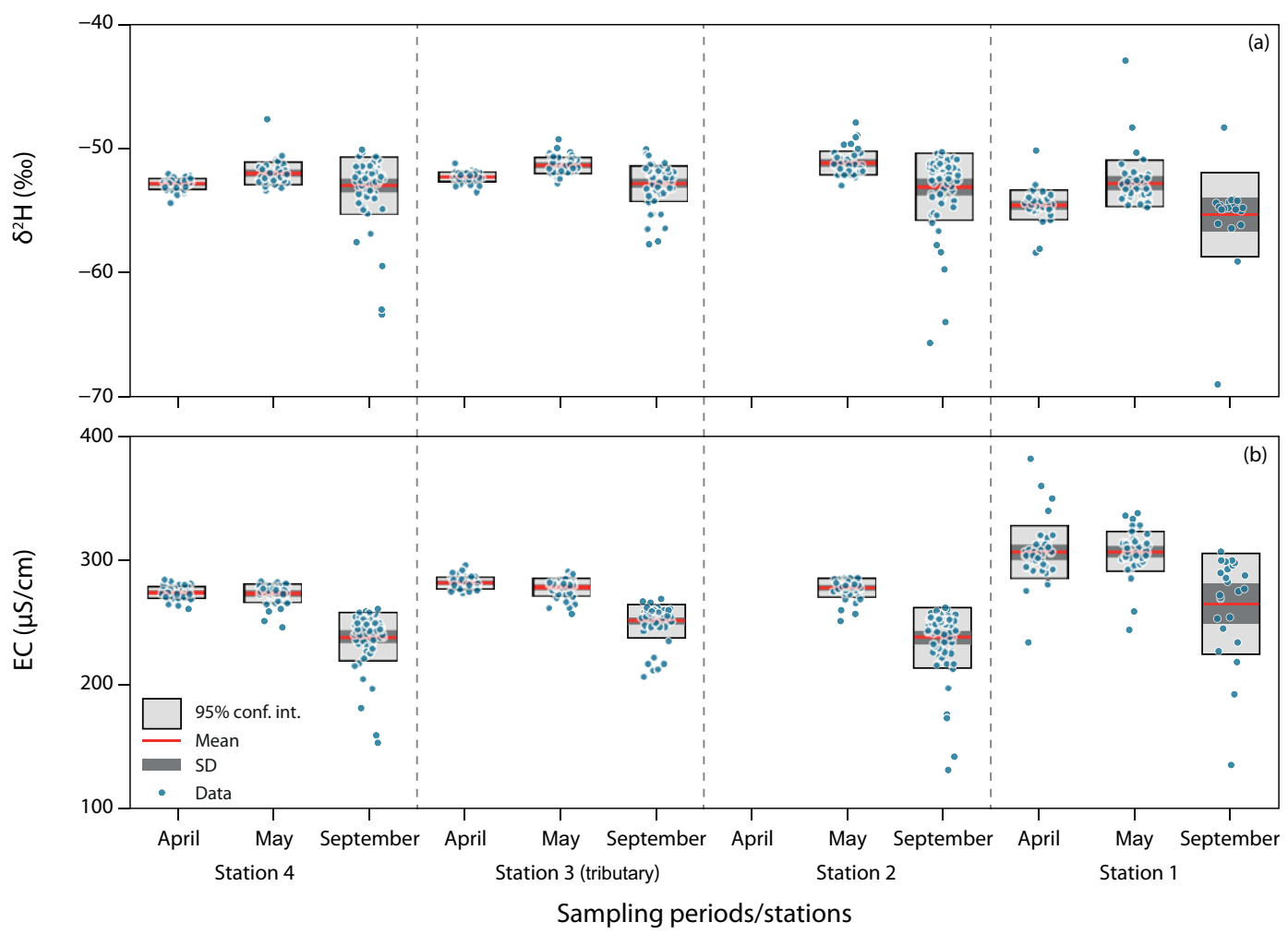

Figure 6. Variability in tracer values measured during event sampling of stream water. (a) $\delta^{2} \mathrm{H}$ and (b) EC values measured in the stream water during the events at the four stations.

also carry the largest amounts of, for instance, nutrients or potential contaminants (with a flux of up to $1.3 \mathrm{~m} \mathrm{day}^{-1}$ in this study), their detection and quantification are of great importance. This is of special interest for gaining lowland streams in agricultural areas due to the potential of high nutrient loads, as also discussed by Krause et al. (2012).

\subsection{Comparison of groundwater discharge measurements at different spatial scales}

So far, only few studies have endeavoured to confirm groundwater discharge sites indicated by the DTS with estimates of discharge based on either seepage metre data or vertical temperature profiles (Lowry et al., 2007; Sebok et al., 2013). This study shows that VTPs generally reflect the same spatial variability in groundwater discharge as the DTS (Fig. 4). There is a discrepancy of estimated fluxes and groundwater signal strength in the case of layout $\mathrm{C}$, which is most likely caused by the reduced difference between the streambed temperatures and groundwater temperature (Fig. 4a). The DTS and VTP measurements of this study mostly complemented each other, confirming that cold streambed temperature anomalies correspond to locations of high upward groundwater fluxes. Thus, the combination of VTP and DTS measurements provides a useful tool for obtaining more robust groundwater discharge estimates in lowland groundwater- dominated streams, where the low temperature contrast between groundwater and surface water prevents discharge calculations by the method of mixing analysis.

The focused discharge locations detected by DTS and confirmed by VTPs agreed well with the net increases in stream discharge as measured by ADCP with the exception that DTS cannot identify losing stream sections. Contrary to the differential flow gauging of Briggs et al. (2011) where an acoustic Doppler velocimeter was used, the ADCP measurements here gave a good estimation of net groundwater discharge between measurement sections of 150-200 m spacing. In this study the combined ADCP and DTS methods made the detailed mapping of gaining and losing stream stretches possible, showing not only the net changes in discharge, but based on DTS also the approximate location of the focused discharge sites. However, a great logistical effort is required in order to map stream stretches longer than a few kilometres.

The discrepancy between the spatial resolutions of the methods is illustrated when comparing the ADCP measurements to the DTS and VTP data. Since the ADCP is expected to measure discharge within an uncertainty of $5 \%$, there exists a lower limit for measurement spacing during differential gauging, since the change in discharge has to differ by more than the $5 \%$. For this study, intervals of approximately 150-200 m were close to the lower limit, especially for layout $\mathrm{A}$ and $\mathrm{C}$, where the most gradual increase in discharge 


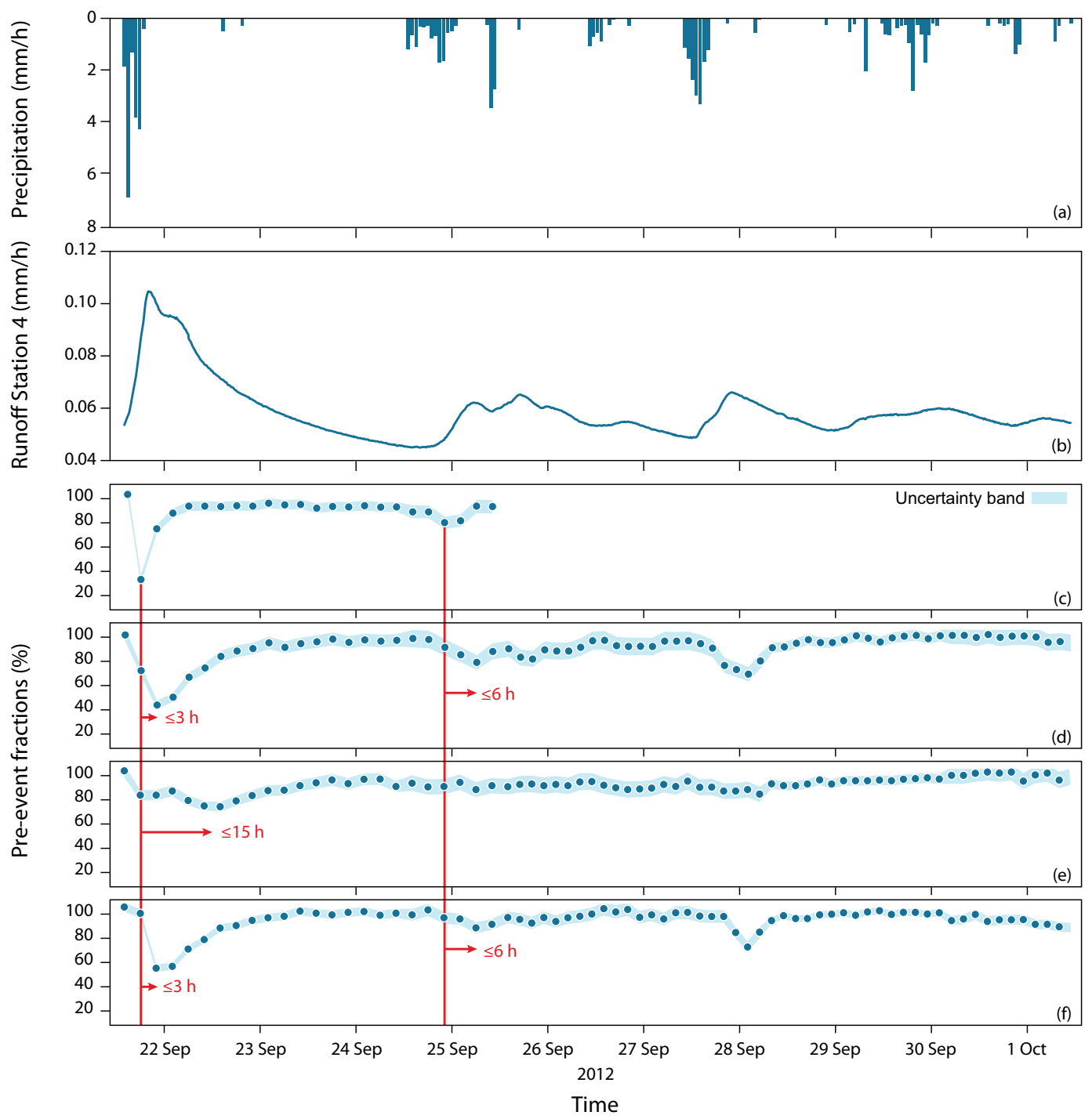

Figure 7. Runoff and precipitation characteristics and pre-event fractions for the September event. (a) Hourly precipitation measured $6 \mathrm{~km}$ northwest of station 4. (b) Catchment runoff measured at station 4. (c-f) Pre-event fractions for stations 1, 2, 3 and 4, respectively. Lag times between peak responses are indicated with red lines.

was observed. Consequently, the ADCP method was not capable of showing the same spatial variability in groundwater discharge as the metre-scale DTS and the point-scale VTP measurements. For this reason, it was also possible to still detect cold temperature anomalies indicating groundwater discharge and relatively high upward fluxes of $0.43 \mathrm{~m} \mathrm{day}^{-1}$ in a stream section of layout $\mathrm{B}$, where ADCP suggested losing conditions (Fig. 4). Due to the diffuse groundwater discharge it is also likely that DTS is only identifying focused discharge areas above a specific flux value marking a detection limit (Sebok et al., 2013). Schmadel et al. (2014) found similar discrepancies between methods mapping discharge across point-to-reach scale. These findings emphasise the importance of combining methods covering different scales to avoid ambiguity or wrong inferences due to interpolation of results between scales.

\subsection{Temporal dynamics and catchment-scale differences in runoff sources and implications for water management}

From the results of the hydrograph separations at the four different stations, it is clear that the most pronounced differences in runoff sources occur between station 1 and station 3 (Fig. 8a), with station 3 indicating a significantly larger and constant groundwater influence during events (maximum event water fraction was $30 \%$ ). The differences in forest cover (Table 1) could explain some of the differences in runoff sources during events since forest cover has previ- 

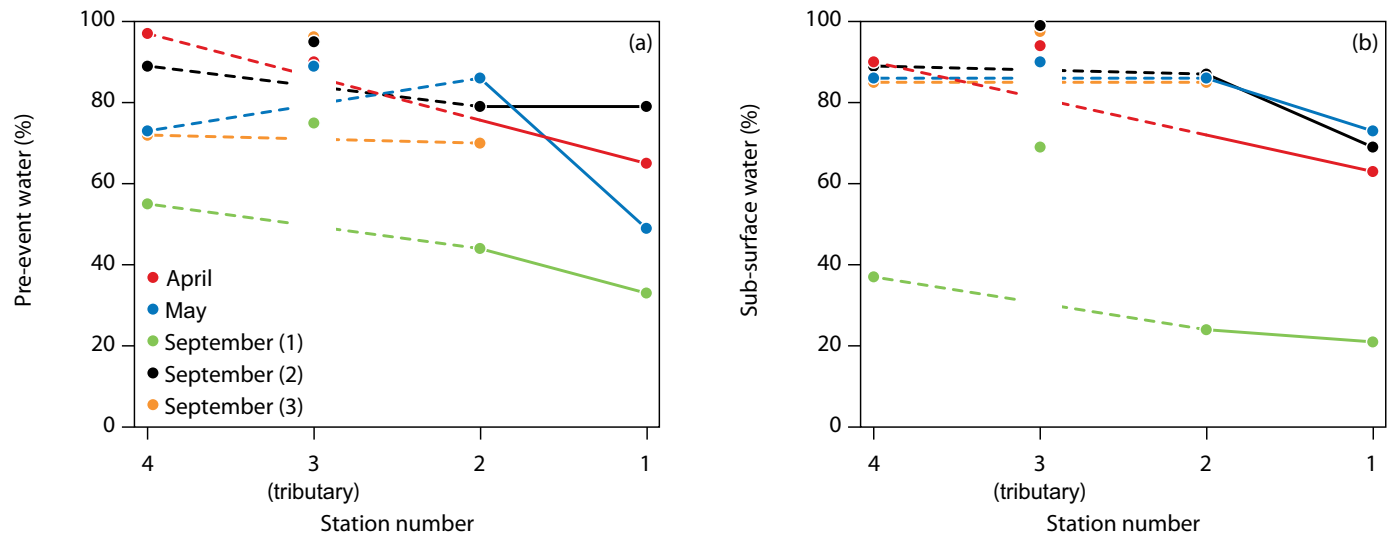

Figure 8. (a) Pre-event fractions and (b) sub-surface fractions for all events. The September event was subdivided into three sub-events September 1 (21-22 September), September 2 (25 September), and September 3 (28 September) and trend lines are added between pre-event and subsurface fractions calculated for the main stream. Uncertainties were less than $10 \%$ for all fractions (not shown).

ously been shown to significantly decrease surface runoff and enhance evaporation (Bosch and Hewlett, 1982; Brown et al., 2005). Also, the fact that station 3 was immediately surrounded by wetlands, while station 1 had a larger proportion of agricultural fields with tile drains in the near-stream area, may explain part of the larger proportion of event water observed at station 1, due to the importance of the riparian zones in terms of runoff processes (Tetzlaff et al., 2014; Vidon and Cuadra, 2010). The consistently high fractions of pre-event water observed at station 3 (Fig. 8a) suggest that the surrounding area has a shallow groundwater table as well as high hydraulic conductivity, allowing precipitation to seep to groundwater and preventing the presence of a zone of stored soil water which could otherwise have created a pre-event soil water component. This is supported by the fact, that no significant differences were seen between preevent fractions and sub-surface fractions at station 3 (Fig. 8). Thus, most likely the assumption of two end members in the hydrograph separation was met, with pre-event water and sub-surface water representing the same groundwater component.

The large contribution from event water (maximum was $65 \%$ event water) at station 1 could also be explained by the observed less strong groundwater gradients towards the stream, compared to the other three stations. Weaker groundwater gradients could potentially allow for a temporarily weakening of the groundwater discharge to the stream during large rain events, entailing a temporary dominance of surface and event water. Similar mechanisms were observed by Karan et al. (2014) where large rain events temporarily decreased groundwater discharge to Holtum stream. Also Gerecht et al. (2011) observed highly dynamic responses to rapid stage changes in terms of shifting between gaining and losing conditions in a groundwater influenced river. These observed differences in responses to large rain events between the studied catchments are of particular interest, in re- lation to being able to predict sensitive areas with the possibility of fast routing of nutrients and pollutants to streams. Catchments reacting similarly to station 1 would be more prone to fast routing of excess nutrients or pollutants than for instance catchments similar to station 3 .

The discrepancies of around 10\% difference observed between subsurface and pre-event factions at stations 1,2 and 4 (Fig. 8) are similar to the findings of Gonzales et al. (2009) for a lowland stream, and could indicate the occurrence of a component which is not accounted for by either of the two hydrograph separation methods (Wels et al., 1991; Hooper and Shoemaker, 1986). According to Karan et al. (2013), a shallow relatively young groundwater component was discharging to the stream at station 4 , supporting the idea that the stream-flow components could be divided into a deep groundwater component discharging right beneath the stream channel, a shallow component and a surface/event water component. However, there was no distinct difference between the average EC and $\delta^{2} \mathrm{H}$ of the shallow soil/groundwater and the deep groundwater. Thus, the prerequisite of distinct differences in end members for a twotracer, three-component hydrograph separation was not met with the given data set (Genereux and Hooper, 1998).

Both the pre-event fractions as well as the subsurface fractions suggested that an event such as the one in April, with $15 \mathrm{~mm}$ rain and a resulting discharge increase of $30-50 \%$, constitutes a threshold below which runoff sources are not altered. These changes in contributing runoff sources between the sub-catchments are contrary to the findings of Gonzales et al. (2009). They found that their studied lowland stream system was at all times groundwater dominated, with minimum $90 \%$ groundwater during events concluding that such consistently high influence of groundwater will most likely be found in the majority of similar lowland stream networks. However, our study illustrates that significant differences in event responses can exist among similar adjacent lowland 
catchments both in terms of the magnitude of event response and the response time (Fig. 7). These differences in catchment runoff sources during large rain events are important to take into account in water management practices, since a significant transport of phosphorus and nitrogen has been shown to be associated with storm events (Jordan et al., 2005; Kronvang and Bruhn, 1996; Stutter et al., 2008). Furthermore, the travel time (Flewelling et al., 2012) and origin (Clément et al., 2003) of discharging groundwater are decisive for the possibility of nitrate reduction.

\section{Conclusions}

Groundwater-surface water dynamics were studied in a groundwater gaining lowland stream in Denmark. The aim of this study was to combine hydraulic and tracer methods from point-to-catchment scale to assess the temporal and spatial variability of groundwater discharge and to assess the capability, limitations and synthesis of novel monitoring methods applied across the different spatial scales in terms of water management practices.

Significant groundwater discharge was observed, resulting in a total stream discharge increase of approximately $30 \%$ over a stream reach of $2400 \mathrm{~m}$. The groundwater discharge was found to be primarily confined in few distinct zones, suggesting the presence of preferential flow paths. The major zones of groundwater discharge were mapped by DTS and ADCP measurements and were supported by point-scale VTP measurements indicating groundwater fluxes of up to $1 \mathrm{~m}^{-1}{ }^{-1}$. This coupling of ADCP, DTS and VTPs proposes a new method to detect areas of concentrated groundwater discharge in detail. The hydrograph separations conducted for the three rain events at the four different stations revealed distinct differences in runoff sources between the four subcatchments. The most pronounced differences in event responses were seen between station 1 and station 3, where station 3 consistently had a minimum of $70 \%$ pre-event water in the stream, whereas station 1 had only $35 \%$ pre-event water during the largest rain event. The event responses were damped downstream indicating an increasing groundwater influence, in agreement with the medium-scale investigations indicating a significant groundwater inflow between station 2 and station 4 .

Based on this study it has been concluded, that despite a significantly groundwater influenced lowland catchment, there is still a high variability in the groundwater-surface water interaction. Hence, in relation to the growing demand of accurately estimating the transport of nutrients and other pollutants to streams, lakes and sea (e.g. European Commission, 2000), our study points to the challenges with variability in runoff sources in lowland streams. Our study emphasises the importance of considering the variability in groundwater discharge to streams across a range of scales. A strong focus should be not only on combining methods on the smaller scales, which has been subject to substantial investigations, but also on seeking to link to the catchment scale, where relatively simple hydrograph separations seem to be a useful tool even in lowland groundwater-dominated streams.

Acknowledgements. We would like to thank members of the Northern Rivers Institute, Aberdeen University, for helpful discussions of data. We also thank Lars Rasmussen, Jolanta Kazmierczak and Charlotte Ditlevsen for help in the field. This study is part of the Hydrology Observatory, HOBE (http://www.hobe.dk), funded by the Villum Foundation and was as well funded by the Aarhus University Research Foundation.

Edited by: G. H. de Rooij

\section{References}

Anibas, C., Buis, K., Verhoeven, R., Meire, P., and Batelaan, O.: A simple thermal mapping method of seasonal patterns of surface water-groundwater interaction, J. Hydrol., 397, 93-104, 2011.

Bencala, K., Gooseff, M. N., and Kimball, B. A.: Rethinking hyporheic flow and transient storage to advance understanding of stream-catchment connections, Water Resour. Res., 47, W00H03, doi:10.1029/2010WR010066, 2011.

Bosch, J. M. and Hewlett, J. D.: A review of catchment experiments to determine the effect of vegetation changes on water yield and evapotranspiration, J. Hydrol., 55, 3-23, 1982.

Boulton, A. J., Datry, T., Kasahara, T., Mutz, M., and Stanford, J. A.: Ecology and management of the hyporheic zone: streamgroundwater interactions of running waters and their floodplains, Stanford Source, J. N. Am. Benthol. Soc., 29, 26-40, 2010.

Bredehoeft, J. D. and Papadopulos, I. S.: Rates of Vertical Groundwater Movement Estimated from the Earth's Thermal Profile, Water Resour. Res., 1, 325-328, 1965.

Briggs, M. A., Lautz, L. K., and McKenzie, J. M.: A comparison of fibre-optic distributed temperature sensing to traditional methods of evaluating groundwater inflow to streams, Hydrol. Process., 25, 1277-1290, doi:10.1002/hyp.8200, 2011.

Brown, A. E., Zhang, L., McMahon, T. A., Western, A. W., and Vertessy, R. A.: A review of paired catchment studies for determining changes in water yield resulting from alterations in vegetation, J. Hydrol., 310, 28-61, 2005.

Brunke, M. and Gonser, T.: The ecological significance of exchange processes between rivers and groundwater, Freshwater Biol., 37, 1-33, 1997.

Clément, J.-C., Aquilina, L., Bour, O., Plaine K., Burt, T. P., and Pinay, G.: Hydrological flowpaths and nitrate removel rates within a riparian floodplain along a fourth-order stream in Brittany (France), Hydrol. Process., 17, 1177-1195, 2003.

Conant, B.: Delineating and quantifying groundwater discharge zones using streambed temperatures, Groundwater, 42, 243-257, 2004.

Dahl, M., Nilsson, B., Langhoff, J. H., and Refsgaard, J. C.: Review of classification systems and new multi-scale typology of groundwater-surface water interaction, J. Hydrol., 344, 1-16, 2007. 
Danish Ministry of Environment: Summary of River Basin Management Plans. Note from the Danish Ministry of Environment, 22 December 2011, 25 pp., see also: http://naturstyrelsen.dk/ vandmiljoe/vandplaner/ (last access: 16 April 2015), 2011.

European Commission: Directive 2000/60/EC of the European Parliament and of the Council establishing a framework for Community action in the field of water policy, Offic. J. Eur. Commun., L327, 1-72, 2000.

Flewelling, S. A., Herman, J. S., Hornberger, G. M., and Mills, A. L.: Travel time controls the magnitude of nitrate discharge in groundwater bypassing the riparian zone to a stream on Virginia's coastal plain, Hydrol. Process., 26, 1242-1253, 2012.

Genereux, D.: Quantifying uncertainty in tracer-based hydrograph separations, Water Resour. Res., 3, 915-919, 1998.

Genereux, D. P. and Hooper, R. P.: Oxygen and hydrogen isotopes in rainfall-runoff studies, in: Isotope Tracers in Catchment Hydrology, edited by: Kendall, C. and McDonnell, J. J., Elsevier Sci., Amsterdam, 1998.

Gerecht, K. E., Cardenas, M. B., Guswa, A. J., Sawyer, A. H., Nowinski, J. D., and Swanson, T. E.: Dynamics of hyporheic flow and heat transport across a bed-to-bank continuum in a large regulated river, Water Resour. Res., 47, 1944-1973, doi:10.1029/2010WR009794, 2011.

Gonzales, A. L., Nonner, J., Heijkers, J., and Uhlenbrook, S.: Comparison of different base flow separation methods in a lowland catchment, Hydrol. Earth Syst. Sci., 13, 2055-2068, doi:10.5194/hess-13-2055-2009, 2009.

Gooseff, M. N.: Defining hyporheic zones-advancing conceptual and operational definitions of where stream water and groundwater meet, Geogr. Compass, 4/8, 945-955, 2010.

Griffith, J., Binley, A., Crook, N., Nutter, J., Young, A., and Fletcher, S.: Streamflow generation in the Pang and Lambourn catchments, Berkshire, UK, J. Hydrol., 330, 71-83, 2006.

Hatch, C. E., Fisher, A. T., Revenaugh, J. S., Constanz, J., and Ruehl, C.: Quantifying surface water-groundwater interactions using time series analysis of streambed thermal records: Method development, Water Resour. Res., 42, W10410, doi:10.1029/2005WR004787, 2006.

Hayashi, M. and Rosenberry, D.: Effects of ground water exchange on hydrology and ecology of surface water, Groundwater, 40, 309-316, 2002.

Herschy, R. W.: Hydometry, Principles and Practices, 2nd Edn., John Wiley \& Sons, Inc., New York, 199.

Hoffmann, C. C. and Baattrup-Pedersen, A.: Re-establishing freshwater wetlands in Denmark, Ecol. Eng., 30, 157-166, 2007.

Hooper, R. P. and Shoemaker, C. A.: A comparison of chemical and isotopic hydrograph separation, Water Resour. Res., 22, 14441454, 1986.

Houmark-Nielsen, M.: The last interglacial-glacial cycle in Denmark, Quartern. Int., 3/4, 31-39, 1989.

Jensen, J. K. and Engesgaard, P.: Nonuniform Groundwater Discharge across a Streambed: Heat as a Tracer, Vadose Zone J., 10, 98-109, doi:10.2136/vzj2010.0005, 2011.

Jordan, P., Arnscheidt, J., McGrogan, H., and McCormick, S.: Highresolution phosphorus transfers at the catchment scale: the hidden importance of non-storm transfers, Hydrol. Earth Syst. Sci., 9, 685-691, doi:10.5194/hess-9-685-2005, 2005.
Kalbus, E., Reinstorf, F., and Schirmer, M.: Measuring methods for groundwater-surface water interactions: a review, Hydrol. Earth Syst. Sci., 10, 873-887, doi:10.5194/hess-10-873-2006, 2006.

Karan, S., Engesgaard, P., Looms, M. C., Laier, T., and Kazmierczak, J.: Groundwater flow and mixing in a wetland-stream system: Field study and numerical modelling, J. Hydrol., 488, 7383, 2013.

Karan, S., Engesgaard, P., and Rasmussen, J.: Dynamic streambed fluxes during rainfall-runoff events, Water Resour. Res., 50, 2293-2311, doi:10.1002/2013WR014155, 2014.

Kasahara, T. and Hill, A. R.: Modeling the effects of lowland stream restoration projects on stream-subsurface water exchange, Ecol. Eng., 32, 310-319, 2008.

Keery, J., Binley, A., Crook, N., and Smith, J. W. N.: Temporal and spatial variability of groundwater-surface water fluxes: Development and application of an analytical method using temperature time series, J. Hydrol., 336, 1-17, 2007.

Krause, S., Heathwaite, A. L., Miller, F., Hulme, P., and Crowe, A.: Groundwater-dependent wetlands in the UK and Ireland: controls, eco-hydrological functions and assessing the likelihood of damage from human activities, J. Water Resour. Manage., 21, 2015-2025, 2008.

Krause, S., Blume, T., and Cassidy, N. J.: Investigating patterns and controls of groundwater up-welling in a lowland river by combining Fibre-optic Distributed Temperature Sensing with observations of vertical hydraulic gradients, Hydrol. Earth Syst. Sci., 16, 1775-1792, doi:10.5194/hess-16-1775-2012, 2012.

Kronvang, B. and Bruhn, A. J.: Choice of sampling strategy and estimation method for calculating nitrogen and phosphorus transport in small lowland streams, Hydrol. Process., 10, 1483-1501, 1996.

Kronvang, B., Jeppesen, E., Conley, D. J., Søndergaard, M., Larsen, S. E., Ovesen, N. B., and Carstensen, J.: Nutrient pressures and ecological responses to nutrient loading reductions in Danish streams, lakes and coastal waters, J. Hydrol., 304, 274-288, 2005.

Landon, M. K., Rus, D. L., and Harvey, F. E.: Comparison of Instream Methods for Measuring Hydraulic Conductivity in Sandy Streambeds, Groundwater, 39, 870-885, 2001.

Langhoff, J. H., Rasmussen, K. R., and Christensen, S.: Quantification and regionalization of groundwater-surface water interaction along an alluvial stream, J. Hydrol., 320, 342-358, doi:10.1016/j.jhydrol.2005.07.040, 2006.

Lischeid, G.: Combining Hydrometric and Hydrochemical Data sets for Investigating Runoff Generation Processes: Tautologies, Inconsistencies and possible explanations, Geogr. Compass, 2/1, 255-280, 2008.

Lowry, C. S., Walker, J. F., Hunt, R. J., and Anderson, M. P.: Identifying spatial variability of groundwater discharge in a wetland stream using a distributed temperature sensor, Water Resour. Res., 43, W10408, doi:10.1029/2007WR006145, 2007.

Malcolm, I. A., Youngson, A. F., and Soulsby, C... Survival of salmonid eggs in a degraded gravel-bed stream: effects of groundwater-surface water interactions, River Res. Appl., 19, 303-316, 2003.

Matheswaran, K., Blommer, M., Rosbjerg, D., and Bøgh, E.: Seasonal variations in groundwater upwelling zones in a Danish lowland stream analyzed using Distributed Temperature Sensing 
(DTS), Hydrol. Process., 28, 1422-1435, doi:10.1002/hyp.9690, 2012.

McCallum, J. L., Cook, P. G., Berhane, D., Rumpf, C., and McMahon, G. A.: Quantifying groundwater flows to streams using differential flow gauging and water chemistry, J. Hydrol., 416-417, 118-132, 2012.

McDonnell, J. J., Bonell, M., Stewart, M. K., and Pearce, A. J.: Deuterium Variations in Storm Rainfall: Implications for Stream Hydrograph Separation, Water Resour. Res., 26, 455-458, 1990.

Mueller, D. S. and Wagner, C. R.: Measuring Discharge with Acoustic Doppler Current Profilers from a Moving Boat, in: Chapter 22, Book 3, Section A, US Geological Survey, Reston, Virginia, 2009.

Muste, M., Yu, K., Pratt, T., and Abraham, D.: Practical aspects of ADCP data use for quantification of mean river flow characteristics; Part II: fixed-vessel measurements, Flow Meas. Instrum., 15, 17-28, 2004a.

Muste, M., Yu, K., and Spasojevic, M.: Practical aspects of ADCP data use for quantification of mean river flow characteristics; Part I: moving-vessel measurements, Flow Meas. Instrum., 15, 1-16, 2004b.

Pinder, G. F. and Jones, J. F.: Determination of ground-water component of peak discharge from chemistry of total runoff, Water Resour. Res., 5, 438-445, doi:10.1029/WR005i002p00438, 1969.

Rantz, S. E.: Measurement and computation of streamflow: Volume 1. Measurement of stage and discharge, United States Geological Survey, Washington DC, 1982.

Ringgaard, R., Herbst, M., Friborg, T., Schelde, K., Thomsen, A., and Søgaard, H.: Energy fluxes above three disparate surfaces in a temperate meso-scale coastal catchment, Vadose Zone J., 10, 54-66, 2011.

Rodhe, A.: Snowmelt-dominated systems, in: Isotope Tracers in Catchment Hydrology, edited by: Kendall, C. and McDonnell, J. J., Elsevier Sci., Amsterdam, 391-433, 1998.

Rosenberry, D. O.: A seepage meter designed for use in flowing water, J. Hydrol., 359, 118-130, 2008.

Scanlon, B. R., Healy, R. W., and Cook, P. G.: Choosing appropriate techniques for quantifying groundwater recharge, Hydrogeol. J., $10,18-39,2002$.

Schmadel, N. M., Neilson, B. T., and Kasahara, T.: Deducing the spatial variability of exchange within a longitudinal channel water balance, Hydrol. Process., 28, 3088-3103, 2014.

Schmidt, C., Contant, B., Bayer-Raich, M., and Schirmer, M.: Evaluation and field-scale application of an analytical method to quantify groundwater discharge using mapped streambed temperatures, J. Hydrol, 347, 292-307, 2007.
Sebok, E., Duque, C., Kazmierczak, J., Engesgaard, P., Nilsson, B., Karan, S., and Frandsen, M.: High-resolution distributed temperature sensing to detect seasonal groundwater discharge to Lake Væng, Water Resour. Res., 49, 5355-5358, doi:10.1002/wrcr.20436, 2013.

Sebok, E., Duque, C., Engesgaard, P., and Boegh, E.: Spatial variability in streambed hydraulic conductivity of contrasting stream morphologies: channel bend and straight channel, Hydrol. Process., doi:10.1002/hyp.10170, 2014.

Selker, J. S., Thévenaz, L., Huwald, H., Mallet, A., Luxemburg, W., van de Giesen, N., Stejskal, M., Zeman, J., Westhoff, M., and Parlange, M. B.: Distributed fiber-optic temperature sensing for hydrologic systems, Water Resour. Res., 42, W12202, doi:10.1029/2006WR005326, 2006a.

Selker, J. S., van de Giesen, N., Westhoff, M., Luxemburg, W., and Parlange, M. B.: Fiber optics opens window on stream dynamics, Geophys. Res. Lett., 33, L24401, doi:10.1029/2006GL027979, 2006b.

Sklash, M. G. and Farvolden, R. N.: Role of groundwater in storm runoff, J. Hydrol., 43, 45-65, doi:10.1016/0022-1694(79)90164$1,1979$.

Stutter, M. I., Langan, S. J., and Cooper, R. J.: Spatial contributions of diffuse inputs and within-channel processes to the form of stream water phosphorus over storm events, J. Hydrol., 350, 203-214, doi:10.1016/j.jhydrol.2007.10.045, 2008.

Tetzlaff, D., Birkel, C., Dick, J., Geris, J., and Soulsby, C.: Storage dynamics in hydropedological units control hillslope connectivity, runoff generation and the evolution of catchment transit time distributions, Water Resour. Res., 50, 969-985, doi:10.1002/2013WR014147, 2014.

Tyler, S. W., Selker, J. S., Hauser, M. B., Hatch, C. E., Torgersen, T., Thodal, C. E., and Schladow, G.: Environmental temperature sensing using Raman spectra DTS fiber-optic methods, Water Resour. Res., 45, W00D23, doi:10.1029/2008WR007052, 2009.

Uhlenbrook, S. and Hoeg, S.: Quantifying uncertainties in tracerbased hydrograph separations: a case study for two-, three- and five-component hydrograph separations in a mountainous catchment, Hydrol. Process., 17, 431-453, 2003.

Vidon, P. and Cuadra, P. E.: Impact of precipitation characteristics on soil hydrology in tile-drained landscapes, Hydrol. Process., 24, 1821-1833, doi:10.1002/hyp.7627, 2010.

Wels, C., Cornett, R. J., and Lazerte, B. D.: Hydrograph separation: A comparison of geochemical and isotopic tracers, J. Hydrol., 122, 253-274, 1991.

Winter, T. C.: Relation of streams, lakes, and wetlands to groundwater flow systems, J. Hydrogeol., 7, 28-45, 1999. 